Article

\title{
The Link between Tax Revenue Components and Economic Growth: Evidence from South Africa. An ARDL Approach
}

\section{Author: Dumisani Pamba}

${ }^{1}$ School of Accounting, Economics and Finance, University of KwaZulu-Natal, Westville, Durban. South Africa, 217076475@stu.ukzn.ac.za

*Correspondence: 217076475@stu.ukzn.ac.za

Abstract: This study examined the link between tax revenue components and economic growth in South Africa, utilizing time series data for the period of 22 years. The stationarity of the variables was established using the Phillips-Perron (PP) unit root test, and the existence of long-run and short-run equilibrium conditions was tested using the Autoregressive Distributed Lag (ARDL) model. As a proxy for economic growth, the study used the real GDP growth rate as the dependent variable, with company income tax, personal income tax, taxes on international trade and transactions, taxes on income, profits, and capital gains tax, foreign direct investment, inflation, and gross savings as the independent variables. According to the PP findings, none of the variables are integrated at a higher order than one, i.e. (1). All variables are found to be cointegrated, and all explanatory variables have a long-run link with economic growth. According to the ARDL findings, company income tax, personal income tax, and taxes on international trade and transactions all have a positive long-run and short-run link with economic growth, whereas capital gain tax, foreign direct investment, and gross savings all have a negative long-run and short-run link with economic growth. The long-run coefficient is negatively related to RGDP, while the short-run coefficient revealed a positive link between inflation and economic growth, among other findings. Heteroskedasticity and autocorrelation are not present in our model, according to diagnostic tests. The CUSUM and CUSUMSQ values indicate that the model is structurally sound.

Keywords: Tax Revenue; FDI; Inflation; Gross Savings; Economic Growth; ARDL Model. JEL Classification: H2, E62, C32. 


\section{Introduction}

The link between tax revenue and economic growth has long been a source of contention in public finance and macroeconomics. However, many questions remain unanswered, and the empirical link between taxes and growth appears to be far more complex than theoretical findings suggest. Some studies discovered a strong link (Skinner, 1987; King and Rabelo, 1990; Arnold et al. (2011). Helms (1985) investigated the impacts of raising state and local taxes. He contends that tax increases may stimulate growth if used to fund development costs, whereas Dowrik (1992) and Saibu (2015) found that taxation has a strong adverse effect on economic growth. In contrast, Roshaiza et al. (2011) found that changes in taxation have no effect on economic growth in their study. In its most basic form, tax is a monetary payment made by the public to the government in exchange for services provided indirectly to the public by the government (Ahmad and Sial, 2016). It is also seen as a required payment given by people and organizations to fulfill government expenses (Dandago and Alabede 2001). Taxation is critical in a developing country like South Africa for promoting long-term growth and poverty reduction. Governments, according to Hijazi (2001), use taxes to increase the state's economic and productive efficiency by monitoring and fully exploiting economic resources.

The primary goal of taxation is to fund public expenditures and redistribute wealth, which translates to funding the country's development. The best way to design a tax system depends on a variety of factors and varies from country to country. It is critical to understand how different taxes distort and harm economic growth in order to design effective tax systems (Nantob, 2014). According to various studies, raising consumption taxes while lowering labor and capital taxes can stimulate the economy's growth forces. According to economic theory, taxes (except for lump sum taxes) cause distortions, which have a negative impact on economic growth. According to Fjeldstad (2013), an efficient tax system is critical for long-term development as it can mobilize the homegrown revenue base as a vital tool for developing nations to liberate from aid or reliance on a single natural resource. Whether the taxes collected are sufficient to finance the country's development will depend on the country's necessities, and countries might seek alternate sources of revenue to finance long-term development (Unegbu and Irefin, 2011). In order 
to achieve economic growth and fiscal consolidation, tax efficiency, particularly the tax structure, is critical. According to Naiyeju (1996), the success or failure of any tax system is determined by how well it is administered and how well the tax legislation is understood and applied.

South Africa undertook a reform of its inherited tax system after obtaining democracy in 1994. That was an once-in-a-lifetime opportunity to create a tax structure appropriate for a market economy. The major goal of the reform was to create a neutral tax system, that is, a tax system that interferes as little as possible in the economic behavior of economic subjects, hence assuring economic efficiency and prosperity. The National Treasury (Department of Finance) in South Africa develops the tax policy framework, and it collaborates closely with the South African Revenue Service (SARS) to ensure that tax policy and tax administration are effectively matched. The laws that the Commissioner must enforce govern South Africa's tax system. The most notable of these are the Income Tax Act 58 of 1962, the VAT Act 89 of 1991, and the Customs and Excise Act 91 of 1964.

South Africa's economy is heavily reliant on tax revenue as a source of government expenditure for development. Personal income tax (PIT), corporate income tax (CIT), and value-added tax (VAT) generate the majority of national tax collections. A fair and equitable tax system is a pillar of South African democracy, reflecting the principles of social solidarity enshrined in the country's constitution. One of the primary issues that a developing country like South Africa faces is a lack of tax revenue. SARS has, on the other hand, played an important role in the development of the democratic state by ensuring that projected levels of revenue are available to support expenditure programs (Budget Review, 2017). South Africa has a taxation system based on residency. Residents are taxed on their whole income, regardless of where it was earned, subject to specific exceptions. Non-residents are only taxed on income earned in South Africa, subject to relief under Double Taxation Agreements (DTAs). Foreign taxes are deducted from the South African tax due on foreign income.

In comparison to other emerging nations, South Africa suffers an overabundance of difficulties, including high unemployment, growing economic and social inequality, sluggish economic growth, high public debt, and low foreign direct investment. Instead of 
declining, the unemployment rate has risen from 17\% in 1994 to 26.7 percent in 2016 . (Stats SA, 2017). In 2014 (HSRC, 2014), the country's Gini coefficient, which measures income inequality, was reported to be 0.63 , making it one of the highest in the world. South Africa's debt-to-GDP ratio was 50.7 percent in 2016, according to Budget Review (2017), up from 27.80 percent in 2008. In 2015, the GDP growth rate was 1.3 percent, up from 0.3 percent in 2016.

The purpose of this paper is to provide a better understanding of revenue growth by uncovering numerical values and determining its influence on South African economic growth. The question of particular interest is whether South Africa's revenue generation capacity is sufficient to support output growth. Aside from government expenditure, one aspect of public sector economics that has received a lot of attention is the economic impact of government tax collection on economic growth. The link between tax revenue and economic growth has long been a contentious topic in the public finance literature, having a complicated link (Dackehag and Hansson, 2012). Whereas, Takumah, (2014) argues that the role of taxation in prompting economic growth is of long-standing interest to academics as well as economic policymakers and tax professionals.

In light of this motivational contextual, the purpose of this article is to assess the role of tax revenue in contributing to South Africa's long-term growth. The study used a conceptual method to investigate the revenue pattern in post-apartheid South Africa and assess its impact on GDP growth. Policymakers, international financial institutions, and academics will benefit from the conclusions of this study. First, the findings will aid us in determining if tax revenue has an impact on South Africa's economic growth. Second, the findings will provide policymakers with information on the long-term impact of tax policy on economic growth. This may influence their fiscal and monetary policies in the future. Finally, the research will add to the body of knowledge about the link between tax revenue components and economic growth in South Africa.

The paper is arranged as follows after the introduction in Section 1: The literature review is presented in Section 2, and the data, model specification, and technique are discussed in Section 3. Section 4 presents and discusses the empirical findings, and Section 5 brings the research to a close. 


\section{Literature Review.}

Solow (1956) provides an open study on the link between taxes and economic growth. Taxes have no influence on steady state growth, but income tax has a detrimental impact on economic allocation, according to his new classical growth model. Solow went on to say that tax policy has an impact on economic growth because it discourages new investment and entrepreneurial rewards, distorts investment decisions, and discourages work effort and workers' skill acquisition.

There have been many empirical studies conducted to determine the link between economic growth and taxation. However, the results of these studies are often contrary. Some studies have found that taxes have aided in improving the economy's performance, while others have found that taxation reduces output and thus economic growth, and still others have found little evidence to support a strong link between taxation and economic growth.

Takumah (2014) used quarterly data from 1986 to 2010 to investigate the impact of tax revenue on economic growth in Ghana using the VAR framework. According to the findings, there is a short-run and long-run link between tax revenue and economic growth. The findings also revealed a one-way causation between tax revenue and economic growth. The findings validate that tax revenue has a positive and statistically significant influence on economic growth in both the long and short run, demonstrating that tax revenue boosts Ghana's economy. Along the same lines, in his study, Sekou (2015) used the ordinary least square approach to estimate the parameters and discovered that the log population on log volume of trade had a positive and significant coefficient. He claims that in Mali, there is a link between tax collecting and growth. Arisoy and Unlukaplan (2010) look at how the mix of direct and indirect taxes affects economic growth. They use the Feeder Model to extract time series data for the Turkish economy from 1968 to 2006. To confirm the significance, in-between direct and indirect taxes they discover that indirect taxes are positively and significantly correlated, with economic growth. Finally, they argue that if economic growth is to be boosted, the fraction of indirect taxes should be higher than the share of direct taxes. Arnold et al. (2011) concluded that moving the tax base from consumption to property would have a favorable influence on economic growth by 
analyzing yearly data for 21 OECD nations from 1971 to 2004 and applying an error correction model. Using pertinent descriptive statistics and econometric analysis, Ogbonna and Ebimobowei (2012) investigate the impact of tax reforms on economic growth in Nigeria. They discovered that diverse tax reforms are connected to economic growth in a favorable and substantial way, and that tax reforms generate economic growth.

Some research, on the other hand, show a negative link between taxation and economic growth. In a research, Saima et al. (2014) used Johansen's co-integration tests for data estimation and time series data for empirical analysis from 1973 to 2010. They discovered that high taxes in Pakistan have adverse implications on consumption, investment, and, ultimately, GDP. Lee and Roger (2005) used a regression model with cross-country data to investigate how tax policies impact economic growth rates between 1970 and 1997. According to the study, lowering the corporate tax rate by $10 \%$ would increase annual growth by one or two percentage points, implying that corporate taxes have a negative impact on economic growth. Saibu (2015) used the model proposed by Scully (2003) for Cote D'lvoire and discovered that in Nigeria and South Africa, there is a negative association between tax burden and rate of economic growth. Anne (2014) found a negative but insignificant influence of income taxes on the Kenyan economy using Ordinary Least Squares, Unit Root tests, Johanssen Cointegration Test, and Vector Error Correction Model (VECM) in her own study. Another research, conducted by Yaya (2013), using the Branson and Lovell (2001) linear programming-based approach, Data Envelopment Analysis (DEA) for New Zealand, and found that higher taxes are linked to lower economic growth. Margareta and Åsa (2012) used fixed effects regression on a panel data set of 25 OECD nations from 1970 to 2010 and found that both company and personal income taxes had a negative impact on economic growth. In addition, Njogu (2015) used a Poisson regression model to investigate the impact of value added tax revenue on economic growth in Kenya from 1990 to 2014. According to the study, every unit loss in tax revenue results in a 7 percent rise in the impact rate of GDP. As a result, it can be inferred that in Kenya throughout the study period, there is a considerable negative association between tax revenue and GDP. 
Some research yielded varied findings. Keho (2011) uses the ARDL technique to examine the link between various taxes and output in Cote d'Ivoire from 1960 to 2006. The study's findings show that, with the exception of real GDP and direct taxes, all variables are co integrated in the long term. Except for direct taxes, all taxes have a positive correlation with economic growth. The change of direct taxes into indirect taxes, as suggested by a policy recommendation research, is one way to boost economic growth. Similarly, Umoru and Anyiwe (2013) investigate the impact of Nigeria's tax structure on economic growth. They used empirical estimation methods such as co-integration and error correction, as well as an empirical disaggregation approach. They discovered that direct taxes has a significant and positive correlation with economic growth, but indirect taxation has a moderate negative influence.

Other studies have found no evidence of a substantial link between taxation and economic growth. Taha et al. (2011) utilize time series data from 1970 to 2009 , including 40 observations, to examine the link between government revenues and economic growth in Malaysia. They looked at the short- and long-run causal relationships between these two variables. The findings reveal that there is a one-way relationship between economic growth and tax collections. Changes in taxes have little effect on economic growth, but increased economic growth boosts tax collections.

The studies above revealed that the link between taxation and economic growth varies by country. Overall, the majority of studies concluded that taxation is associated with positive economic growth, with only a few studies finding no conclusive evidence to support these hypotheses. It is inappropriate to make any generalizations about the potential link between economic growth and taxation in the context of South Africa based on these mixed results. What is clear is that, while different combinations and magnitudes of taxes have different effects on real activities, there is a clear and significant relationship between tax revenue and real economic activity.

Regressions of the OLS model, co-integration, and error correction model (ECM) are chosen and utilized as statistical methods in the majority of studies. Other statistical approaches, such as ARDL and the VAR model, were also used in several research. 
Finally, most of the publications offer a bigger sample of nations, with the majority of them focusing on Asia and Africa.

\section{Methodology}

\subsection{Data and Source.}

This research is structured to make use of time series data. In essence, this enables the researcher to determine the impact of various tax revenue components on economic growth in South Africa from 1994 to 2015. All the data were obtained from the South African Reserve Bank (SARB).

Table 1. Summary of Variables and Expected Signs of their Coefficients.

\begin{tabular}{lcc}
\hline Variables explanations & $\begin{array}{c}\text { Variables } \\
\text { symbols }\end{array}$ & $\begin{array}{c}\text { Expected, a } \\
\text { prior }\end{array}$ \\
\hline $\begin{array}{l}\text { Real GDP growth rate } \\
\text { Tax payable by companies as percentage of total revenue. }\end{array}$ & RGDP & + (positive) \\
Tax payable by persons and individuals as ratio of total & PIT & + (positive) \\
revenue. & ITT & + (positive) \\
$\begin{array}{l}\text { Taxes on international trade and transactions: ratio of total } \\
\text { revenue. }\end{array}$ & CGT & + (positive) \\
$\begin{array}{l}\text { Taxes on income, profits and capital gains as ratio of total } \\
\text { revenue. }\end{array}$ & FDI & + (positive) \\
Ratio of total foreign debt to gross domestic product. & INF & + (positive/neg) \\
Inflation as a GDP deflator. & SAV & + (positive) \\
\hline Gross Saving divided by GDP. & &
\end{tabular}

\subsection{Model Specification}

The model will be built using empirical evidence showing tax revenue variables have a beneficial impact on South Africa's economic growth. As a result, the model specification's functional form will be:

$$
R G D P_{t}=\left(C I T_{t}+P I T_{t}+I T_{t}+C G T_{t}+F D I_{t}+I N F_{t}+S A V_{t}\right)
$$

The variables are then represented as follows in their linear form:

$$
R G D P_{t}=\beta_{0}+\beta_{1} C I T_{t}+\beta_{2} P I T_{t}+\beta_{3} I T T t+\beta_{4} C G T_{t}+\beta_{5} F D I_{t}+\beta_{6} I N F_{t}+\beta_{7} S A V_{t}+\mu_{t}
$$

Equation (2) is written as follows in the context of a log-linear model:

$\operatorname{RGDP}_{t}=\beta_{0}+\beta_{1} \operatorname{lnCIT} t+\beta_{2} \operatorname{lnPIT_{t}}+\beta_{3} \operatorname{InITT_{t}}+\beta_{4} \operatorname{lnCGT_{t}}+\beta_{5} \operatorname{lnFDIt}+\beta_{6} \operatorname{InINF}_{t}+\beta_{7} \operatorname{lnSAV} t+$ 
$\beta_{0}$, is intercept, $\beta_{1}$ to $\beta_{7}$ are the slopes of the independent variable coefficients to be determined, and $\mu \mathrm{t}$ is the error term at time t.

To determine the short-run and long-run links between the tax revenue variables of interest and economic growth, we use the Autoregressive Distributed Lag (ARDL) Bounds testing technique developed by Pesaran et al (2001). The ARDL approach has the benefit of handling integer or fractional order of integration and does not impose the restrictive premise that all variables under investigation must be integrated in the same order, avoiding the need to evaluate the order of integration of variables. This technique works whether the variables are all $\mathrm{I}(1)$ or a mix of $\mathrm{I}(0)$ and $\mathrm{I}(1)$.

Since ARDL is sensitive to variables that are I(2), this study will first test all of the variables for stationarity, in order to identify the orders of integration of each variable, using the Phillips-Perron (PP) tests of stationarity. Aside from the statistical properties of the ARDL approach, another benefit is that estimations may be performed even when the explanatory variables are endogenous, which is typical in growth models. This, according to Pesaran and Shin (1999), is due to the fact that the model contains the lags of both the dependent and explanatory variables. Finally, this approach works well even with small samples.

Equation 3 is transformed as follows to represent the conditional ARDL economic growth model:

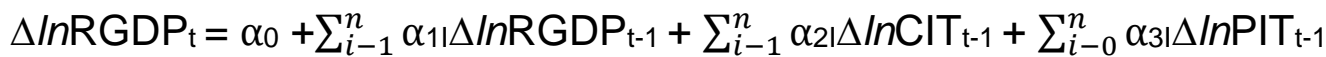

$$
\begin{aligned}
& +\sum_{i-0}^{n} \alpha_{4 \mid} \Delta / n \mathrm{TTT}_{\mathrm{t}-1}+\sum_{i-0}^{n} \alpha_{5 i} \Delta / n \mathrm{CGT}_{\mathrm{t}-1}+\sum_{i-1}^{n} \alpha_{61} \Delta / n \mathrm{FDI}_{\mathrm{t}-1}+ \\
& \sum_{i-1}^{n} \alpha_{7 \mid} \Delta / n \mathrm{NFF}_{\mathrm{t}-1}+\sum_{i-1}^{n} \alpha_{81} \Delta / n S A \mathrm{~V}_{\mathrm{t}-1}+\beta_{1} \operatorname{lnRGDP} \mathrm{RG}_{t-1}+\beta_{2} \ln \mathrm{CIT}_{\mathrm{t}-1}+ \\
& \beta_{3} \operatorname{InPIT} \mathrm{t}_{-1}+\beta_{4} \operatorname{InITT}_{\mathrm{t}-1}+\beta_{5} \operatorname{lnCGT} \mathrm{t}_{\mathrm{t}-1}+\beta_{6} \operatorname{lnFDIt-1}+
\end{aligned}
$$

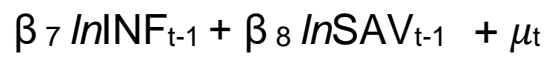

Where $\Delta$ is the first difference operator, the short run and long run elasticities are $\alpha_{1}, \ldots$, $\alpha_{8}$ and $\beta_{1}, \ldots, \beta_{8}$ respectively, and $\mu$ t is the error term.

Essentially, the ARDL bounds test involves testing the null hypothesis, which specifies no existence of long run link among the variables, that is $H_{0}: \beta_{1}=\beta_{2}=\beta_{3}=\beta_{4}=\beta_{5}=\beta_{6}=\beta_{7}$ 
$=\beta_{8}=0$ against the alternative hypothesis of the existence of a long run relationship among the variables, that is $H_{1}: \beta_{1} \neq \beta_{2} \neq \beta_{3} \neq \beta_{4} \neq \beta_{5} \neq \beta_{6} \neq \beta_{7} \neq \beta_{8} \neq 0$.

In order to inspect the cointegration link between tax revenue components and economic growth, we shall take two stages. To assess if there is cointegration among the variables, we first estimate the above equation using the ordinary least square (OLS) approach and then compute the F-statistic for the null hypothesis $H_{0}: \beta_{1}=\beta_{2}=\beta_{3}=\beta_{4}=\beta_{5}=\beta_{6}=\beta_{7}=$ $\beta_{8}=0$ versus the alternative that $H_{1}: \beta_{1} \neq \beta_{2} \neq \beta_{3} \neq \beta_{4} \neq \beta_{5} \neq \beta_{6} \neq \beta_{7} \neq \beta_{8} \neq 0$.

The joint null hypothesis holds in the absence of a long-run level link between tax revenue components and economic growth. The following is how the cointegration test findings should be interpreted: first, if the estimated F-statistic falls between the upper and lower bounds at a given significant level, there is no judgement on whether or not there is cointegration. Second, if the F-statistic exceeds the upper bound, the null hypothesis of "no co-integration" is rejected, while the null hypothesis cannot be rejected if it falls below the lower bound. Regardless of whether the underlying orders of integration of the variables are $\mathrm{I}(0)$ or $\mathrm{I}(1)$, the null hypothesis is accepted.

$$
\begin{aligned}
& \Delta / n \mathrm{RGDP}_{\mathrm{t}}=\alpha_{0}+\sum_{i-1}^{n} \alpha_{11} \Delta / n \mathrm{RGDP}_{\mathrm{t}-1}+\sum_{i-1}^{n} \alpha_{2 \mid} \Delta / n \mathrm{CIT} \mathrm{T}_{\mathrm{t}-1}+\sum_{i-0}^{n} \alpha_{3 \mid} \Delta / n \mathrm{PIT} \mathrm{T}_{\mathrm{t}-1} \\
& +\sum_{i-0}^{n} \alpha_{4 \mid} \Delta / n \mid \mathrm{TT}_{\mathrm{t}-1}+\sum_{i-0}^{n} \alpha_{5 i} \Delta / n \mathrm{CGT}_{\mathrm{t}-1}+\sum_{i-1}^{n} \alpha_{6 \mid} \Delta / n \mathrm{FDI}_{\mathrm{t}-1} \\
& +\sum_{i-1}^{n} \alpha_{7 \mid} \Delta / n \mid \mathrm{NF}_{\mathrm{t}-1}+\sum_{i-1}^{n} \alpha_{81} \Delta / n S A \mathrm{~V}_{\mathrm{t}-1}+\mu_{\mathrm{t}}
\end{aligned}
$$

To estimate the short run coefficients, the long run model is followed by the error correction model given in equation 6 .

$$
\begin{gathered}
\Delta / n R_{\text {RDP }}=\alpha_{0}+\sum_{i-1}^{n} \alpha_{11} \Delta / n \mathrm{RGDP}_{\mathrm{t}-1}+\sum_{i-1}^{n} \alpha_{2 \mid} \Delta / n \mathrm{CIT}_{\mathrm{t}-1}+\sum_{i-0}^{n} \alpha_{3 \mid} \Delta / n \mathrm{PIT}_{\mathrm{t}-1} \\
+\sum_{i-0}^{n} \alpha_{4 \mid} \Delta / n \mid \mathrm{TT}_{\mathrm{t}-1}+\sum_{i-0}^{n} \alpha_{5 i} \Delta / n \mathrm{CGT}_{\mathrm{t}-1}+\sum_{i-1}^{n} \alpha_{6 \mid} \Delta / n \mathrm{FDI}_{\mathrm{t}-1} \\
+\sum_{i-1}^{n} \alpha_{7 \mid} \Delta / n \mathrm{NFF}_{\mathrm{t}-1}+\sum_{i-1}^{n} \alpha_{8 \mid} \Delta / n \mathrm{SAV}_{\mathrm{t}-1}+\lambda \mathrm{ECM}_{\mathrm{t}-1}+\mu_{\mathrm{t}}
\end{gathered}
$$

The short run speed of adjustment back to long run equilibrium is measured by the coefficient of the error correction term (ECM), $\lambda$. It demonstrates how economic growth deviate significantly from long-run equilibrium but steadily returns to it. As a result, the 
ECM's coefficient must be less than one, negative, and statistically significant for the economy to reach equilibrium.

We also run the standard diagnostic tests for serial correlation, normality, and heteroskedasticity to confirm that both equations are correct model specification. Finally, we use the cumulative sum (CUMSUM) and cumulative sum of squares (CUSUMSQ) statistics to test the stability of our estimations.

\section{Results and Discussion.}

\subsection{The Unit Root Test}

To determine the order of integration of the variables, the Phillips-Perron (PP) unit root test is used. The PP compares a unit root's null to the alternative of stationary. The findings in Table 2 demonstrate that none of the variables are integrated at a higher order than one, i.e. I(1), enabling the cointegration test to be used to assess the link between our variables.

Table 2. Unit Root Results.

(a) PP Unit Root Test Result.

\begin{tabular}{lcccc}
\hline \multicolumn{1}{c}{ Variables } & PP Test Stat & $\begin{array}{c}\text { Critical } \\
\text { Value }\end{array}$ & Remark & $\begin{array}{c}\text { Order of } \\
\text { Integration }\end{array}$ \\
\hline InRGDP & -7.125520 & $-2.679735^{\star}$ & Stationary & $\mathrm{I}(1)$ \\
InCIT & -3.729417 & $-2.679735^{\star}$ & Stationary & $\mathrm{I}(1)$ \\
InPIT & -2.978720 & $-2.679735^{\star}$ & Stationary & $\mathrm{I}(1)$ \\
InITT & -3.819191 & $-2.679735^{\star}$ & Stationary & $\mathrm{I}(1)$ \\
InCGT & -3.671000 & $-.2 .679735^{\star}$ & Stationary & $\mathrm{I}(1)$ \\
InFDI & -4.166858 & $-2.679735^{\star}$ & Stationary & $\mathrm{I}(1)$ \\
InINF & -5.418436 & $-2.679735^{\star}$ & Stationary & $\mathrm{I}(1)$ \\
InSAV & -4.462865 & $-2.679735^{\star}$ & Stationary & $\mathrm{I}(1)$ \\
\hline
\end{tabular}

Note. $\left.{ }^{\star}{ }^{\star}\right)$ indicate significant at $1 \%$. All the variables are log linearized. Source: Authors' computation

\subsection{Optimal Lag Selection and Cointegration test results.}

Based on the number of regressors included in the growth model, the maximum lag length selected by Akaike information criterion (AIC) is 1. As a result, the ARDL growth model obtained is $\operatorname{ARDL}(1,0,0,0,0,0,1,0)$. The cointegration link between tax revenue components and economic growth is tested in two phases. We first use the ordinary least square (OLS) technique to estimate equation 4 and then calculate the F-statistic for the 
null hypothesis $\alpha_{1}=\alpha_{8}=0$ versus the alternative $\alpha_{1} \neq \alpha_{8} \neq 0$. There is a steady long-run relationship between tax revenue components and economic growth under the interest alternative. Following the bounds test.

Table 3. F-Bounds Test.

\begin{tabular}{ccccc}
\hline Test Statistic & Value & Signif. & $\mathbf{I}(\mathbf{0})$ & $\mathbf{I}(\mathbf{1})$ \\
\hline F-statistic & $5.999656^{\star \star *}$ & $10 \%$ & 1.92 & 2.89 \\
K & 7 & $5 \%$ & 2.17 & 3.21 \\
& & $2.5 \%$ & 2.43 & 3.51 \\
& & $1 \%$ & 2.73 & 3.9 \\
\hline
\end{tabular}

***,** and ${ }^{*}$ denotes significant at $1 \%, 5 \%$ and $10 \%$ significance level, respectively, ARDL: Autoregressive distributed lag

We reject the null hypothesis of "no cointegration" using the bounds test because the Fstat, 5.999656, is greater than the upper bound, I(1), at $1 \%$ levels of significance. This demonstrates that all of the explanatory variables have a long-run link with economic growth.

\subsection{Long Run and Short Run Analysis.}

The study estimates the long-run coefficients of the $\operatorname{ARDL}(1,0,0,0,0,0,0,1,0)$ selected using the Schwarz Bayesian Criterion, based on the existence of a long-run cointegration relationship between tax revenue variables and economic growth. According to Perasan et al. (1997: 3), the ARDL-Schwarz Bayesian Criterion and the ARDL-Akaike Information Criterion estimates have similar small-sample performances, with the ARDL-Schwarz Bayesian Criterion performing marginally better in most of the experiments, which could be due to the fact that the Schwarz Bayesian Criterion is a consistent model selection criterion while the Akaike Information Criterion is not.

The short-run and long-run dynamics are integrated in the error correction representation. The short-run reactions of economic growth to the tax revenue and non-tax revenue variables comprised in equation are represented by the coefficients of the variables in the error correction model given below (4). 
Table 4. Long Run and Short Run Results

\begin{tabular}{|c|c|c|c|c|}
\hline \multicolumn{5}{|l|}{$\begin{array}{l}\text { Panel 1: Long } \\
\text { run }\end{array}$} \\
\hline Variable & Coefficient & Std. Error & t-Statistic & Pro. \\
\hline $\ln \mathrm{CIT}$ & 3.158911 & 12.51988 & 0.252312 & 0.8092 \\
\hline InPIT & 3.092702 & 12.55623 & 0.246308 & 0.8137 \\
\hline InITT & 0.259048 & 0.880691 & 0.294141 & 0.7786 \\
\hline InCGT & -3.289935 & 12.39361 & -0.265454 & 0.7995 \\
\hline InFDI & -0.140725 & 0.078098 & -1.801894 & 0.1216 \\
\hline InINF & -0.003975 & 0.211966 & -0.018754 & 0.9856 \\
\hline InSAV & -0.472232 & 0.405412 & -1.164818 & 0.2883 \\
\hline $\mathrm{C}$ & 23.76293 & 17.66351 & 1.345312 & 0.2271 \\
\hline \multicolumn{5}{|l|}{$\begin{array}{l}\text { Panel 2: Short } \\
\text { run }\end{array}$} \\
\hline Variable & Coefficient & Std. Error & t-Statistic & Pro. \\
\hline$\Delta \mathrm{CIT}$ & 5.574453 & 4.569273 & 1.219987 & 0.2682 \\
\hline$\Delta \mathrm{PIT}$ & 5.467135 & 4.626509 & 1.181698 & 0.2820 \\
\hline$\Delta \mathrm{ITT}$ & 0.590476 & 0.495952 & 1.190591 & 0.2788 \\
\hline$\Delta \mathrm{CGT}$ & -5.726491 & 4.603348 & -1.243984 & 0.2599 \\
\hline$\Delta \mathrm{FDI}$ & -0.304931 & 0.086907 & -3.508715 & $0.0127^{\star \star}$ \\
\hline$\Delta \mathrm{INF}$ & 0.381060 & 0.129372 & 2.945458 & $0.0258^{\star \star}$ \\
\hline$\triangle S A V$ & -0.618831 & 0.297386 & -2.080901 & $0.0826^{\star \star \star}$ \\
\hline $\operatorname{ECM}(-1)$ & -1.553186 & 0.316810 & -4.902574 & $0.0027^{\star * \star}$ \\
\hline R-squared & 0.839401 & \multicolumn{2}{|c|}{ Mean dependent var } & -0.131818 \\
\hline Adjusted R-square & 0.759102 & \multicolumn{2}{|c|}{ S.D. dependent var } & 1.864298 \\
\hline S.E. of regression & 0.915023 & \multicolumn{2}{|c|}{ Akaike info criterion } & 2.935552 \\
\hline Sum squared resic & 11.72174 & \multirow{2}{*}{\multicolumn{2}{|c|}{$\begin{array}{l}\text { Schwarz criterion } \\
\text { Hannan-Quinn criter. }\end{array}$}} & 3.332295 \\
\hline Long likelihood & -24.29108 & & & 3.029013 \\
\hline Durbin-Watson sta & 2.524905 & \multicolumn{2}{|c|}{ Hannan-Quinn criter. } & \\
\hline
\end{tabular}

Without an interaction term between tax revenue components and economic growth, Table 4 shows the ARDL's long and short run relationship. The adjusted $\mathrm{R}^{2}$, or coefficient of multiple determination, calculated from the above result revealed that the independent variables in the model explain $75.9 \%$ of the total variation in the real GDP growth rate.

Furthermore, both the long and short run estimates of company income tax (CIT) in South Africa are positively related to economic growth, implying that a $1 \%$ increase in CIT will result in 3.158911 and 5.574453 more than proportionate increases in economic growth in the long and short run, respectively. The outcome matches the a priori expectation. The findings are consistent with Salami et al. (2015)'s conclusion that corporate income tax is positively connected to GDP. 
The estimated coefficient of personal income tax (PIT) is favorably associated to economic growth in both the long and short run. In the long run and short run, a 1\% rise in personal income tax (PIT) will result in 3.092702 and 5.467135 percent increases in economic growth, respectively. This corresponds to a priori expectations.

Similarly, in the long and short run, taxes on international trade and transactions (ITT) are positively but insignificantly associated to economic growth. This means that a $1 \%$ rise in taxes on international trade and transactions would result in GDP growth of 0.259048 percent in the long run and 0.590476 percent in the short term, respectively.

In contrast, taxes on income, earnings, and capital gains tax (CGT) have a negative estimated long run coefficient. Taxes on income, profits, and capital gains tax (CGT) all have a negative estimated short run coefficient. According to the findings, a $1 \%$ rise in government CGT would cause GDP growth to decline by 3.289935 percent in the long run and 5.726491 percent in the short run, respectively. This contradicts a priori expectations.

While FDI has a long-run negative and substantial relationship with economic growth, it is statistically significant at $1 \%$. In the short run, FDI has a negative impact on economic growth. In other words, a $1 \%$ increase in FDI will result in a 0.140725 and 0.304931 decline in economic growth in the long and short run, respectively. The findings go against a priori expectation.

Inflation (INF) has a long-run negative relationship with economic growth. In the long run, a unit rise in inflation will result in a 0.003975 decline in economic growth. Inflation's shortrun estimated coefficient, on the other hand, is positively connected to economic growth. In the short run, a unit rise in inflation causes an increase in economic growth of 0.381060 .

The long and short run estimates of gross domestic saving (SAV) are both adversely connected to economic growth, with the short run estimate being $10 \%$ significant. In the long run and short run, a percent rise in SAV will result in 0.472232 and 0.618831 decreases in economic growth, respectively. As a result, gross domestic savings have no direct effect on South Africa's economic growth. This is in direct opposition to the a priori expectation. 
The -1.553186 Error Correction Model (ECM (-1) coefficient had a correct negative sign and was statistically significant at $1 \%$. This demonstrates that a short-run deviation from $(0.0027)$ can be corrected quickly. This conclusion clearly demonstrates that in the short run, the long-run in RGDP (economic growth) is swiftly adjusted to equilibrium. We also discovered that the model's Durbin-Watson value was 2.524905, indicating that there is no autocorrelation in the model.

\subsection{Diagnostic tests.}

Finally, as shown in Table 5 and Figure 1, the ARDL model passed all diagnostic tests. The model is free of serial correlation and heteroskedasticity, as seen in Table 5. Furthermore, the stochastic residual follows a normal distribution. All necessary diagnostic tests are met by the estimated model. To verify the stability of the variables in the short and long run, the Cumulative sum (CUSUM) and Cumulative sum of square (CUSUMSQ) tests are used. At a 5\% level of significance, the findings are inside the critical boundaries, showing that the model is stable, consistent, and dependable (Figure 1). Over the sample period 1994-2016, the CUSUM and CUSUMSQ plots demonstrate that the long-run coefficients and all short-run coefficients in ECM are stable and drive economic growth (RGDP).

Table 5. Residual Analysis Results

\begin{tabular}{|c|c|c|}
\hline \multicolumn{3}{|c|}{ RGDP } \\
\hline Tests & Values & P-values \\
\hline Breusch-Godfrey Serial LM & 1.218582 & 0.2696 \\
\hline $\begin{array}{ll}\text { Breusch-Pagan } & \text { Godfrey's } \\
\text { Heteroskedasticity } & \end{array}$ & 13.18239 & 0.1545 \\
\hline Jarque-Bera & 0.335732 & 0.845467 \\
\hline
\end{tabular}

Source: Author's Computation 
Figure 1: Stability Test: CUSUM and CUSUM of Squares

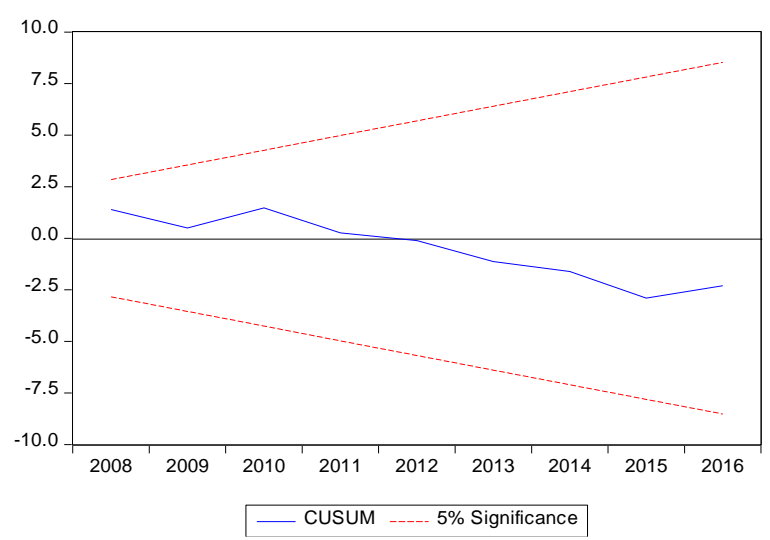

(a)

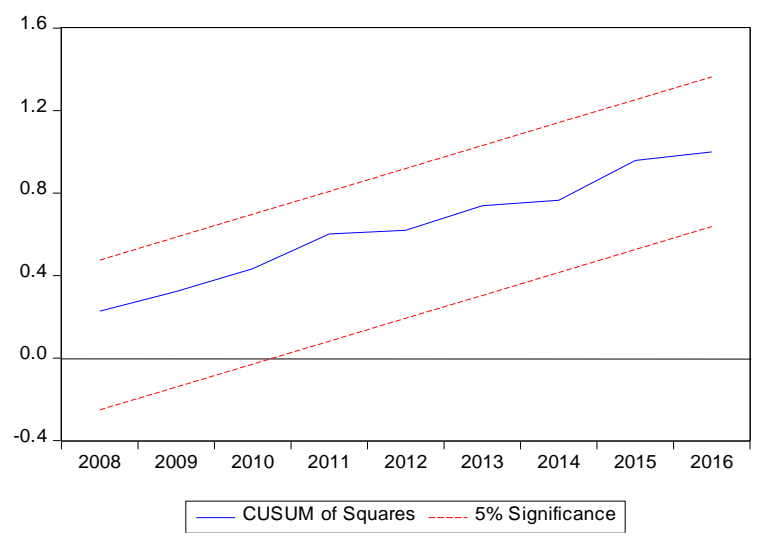

(b)

\section{Conclusion.}

The objective of this article was to look at the link between tax revenue components and South African economic growth. The analysis was carried out using an ARDL model that regressed economic growth on four tax revenue variables as well as three non-tax revenue variables. The time series attributes or level of integration of time series variables were checked using the Phillips-Perron (PP) unit root tests. According to the PhillipsPerron (PP) findings, none of the variables are integrated at a higher order than one, i.e. (1). The short and long run relationship between the variables was established for the period 1994-2016 using the Autoregressive Distributive Lag (ARDL) technique to cointegration. All variables are determined to be cointegrated, and there is a long run link between economic growth and all explanatory variables, according to the Bounds Test. The results of the ADRL long and short run analyses point to an inconsistency in the link between various tax components and economic growth.

Corporate income tax (CIT) is positively associated to economic growth in South Africa, according to the ADRL long and short-term estimates, which means that a $1 \%$ rise in CIT will result in a more than commensurate increase in economic growth in the long run. In a similar line, the estimated coefficient for Personal Income Tax (PIT) is positively associated to economic growth in both the long and short run. In the long run, a $1 \%$ rise in the Personal Income Tax (PIT) will result in increased economic growth. These two forms of taxes account for a significant portion of South Africa's tax revenue. Furthermore, in the long and short run, taxes on international trade and transactions (ITT) are positively 
but insignificantly linked to economic growth. This means that a $1 \%$ rise in international trade and transaction taxes would result in GDP growth in the long and short run, respectively. The estimated long run coefficient for income, profit, and capital gain tax (CGT) is, on the other hand, negative. Taxes on income, profits, and capital gains tax (CGT) all have a negative estimated short run coefficient. According to the findings, a $1 \%$ increase in government CGT would constrain GDP growth in South Africa over the study period.

FDI is adversely and strongly connected to economic growth in the long and short run, and it is statistically significant at $5 \%$ in the short run, among other non-tax revenue variable outcomes. In other words, a $1 \%$ increase in FDI will result in a $1 \%$ drop in economic growth in the long run and a $1 \%$ drop in the short run. This suggests that FDI has little influence on South Africa's growth. Inflation (INF) is inversely associated to economic growth in the long run. In the long-run, a unit increase in inflation will result in a decrease in economic growth. Inflation's short-run estimated coefficient, on the other hand, is positively related to economic growth. In the short run, a unit increase in inflation will boost economic growth. The long and short run estimates for gross domestic saving (SAV) are both adversely connected to economic growth, with the short run estimate being $10 \%$ significant. In the long and short run, a unit increase in gross domestic saving will result in a fall in economic growth rate. As a result, gross domestic savings have no effect on the economic growth process.

The lag value of one period of error term that we derive from the long run relationship is the ECM $(-1)$. ECM $(-1)$ should be a negative and statistically significant coefficient. The ECM term's value indicates that the adjustment process is moderate, and 1.553186 of the previous year's GDP (economic growth) disequilibrium will be addressed in the current year.

Our model is clear of serial correlation and heteroskedasticity, according to diagnostic tests. The distribution of stochastic residuals is normally distributed. Our model is structurally stable, as shown by CUSUM and CUSUMSQ, and lies within the $5 \%$ of critical bounds. 


\section{References}

Ahmad,S and Sial, M.H. 2016. Tax and Economic Growth: An Empirical Analysis of Pakistan. European Journal of Business and Social Sciences, 5, (02), 16-29.

Anne W.H 2014. Income taxes and economic performance in Kenya. A research paper submitted to the University of Nairobi, School of Economics, in Partial fulfilment of the requirements for the award of Master of Arts degree in Economics.

Arisoy, I., and Unlukaplan, I. 2010. Tax Composition and Growth in Turkey: An Empirical Analysis. International Research Journal of Finance and Economics, 59, 50-61.

Arnold, J. M., Brys, B., Heady, C., Johansson, A., Schwellnus, C., and Vartia, L. 2011. Tax Policy for Economic Recovery and Growth. The Economic Journal, 121, F59-F80.

Budget Review. 2017. National Treasury, Republic of South Africa. www.treasury.gov.za/documents/national\%20budget/2017/review/FullBR.pdf [accessed on 14th Oct 2017].

Carroll, C.D. and Weil, D.N. 1994. Saving and Growth: A Reinterpretation. CarnegieRochester Conference Series on Public Policy, 40, 133-192. https://doi.org/10.1016/0167-2231(94)90006-X

Dackehag M, Hansson A. 2012. Taxation of income and economic growth: An empirical analysis of 25 rich OECD countries. Working Paper. Department of Economics, Lund University. 2012; 6.

Dandago, K.I., and Alabede, J O. 2001. Taxation and tax administration in Nigeria. Kano: Triumph Publishing Company Limited.

Dowrick, S. 1992. Technological Catch Up and Diverging Incomes: Patterns of Economic Growth 1960 - 1988. Journal Royal Economic Society, 102(412), 600 - 610.

Fjeldstad, O-H. 2013. A review of donor support to strengthen tax systems in developing countries. WIDER Working Paper No. 2013/010, February.

Helms, L. J. 1965. The Effect of State and Local Taxes on Economic Growth: A Time Series Cross Section Approach. The Review of Economics and Statistics, 67, 574-82. 
Hijazi, A.A. 2001. Tax Systems between Theory and Practice. AL Dar AL Jamiaeah, Beirut.

Human Science Research Council, (HSRC). 2014. Income inequality and limitations of the Gini Index: the case of South Africa. http://www.hsrc.ac.za/en/review/hsrc-reviewnovember-2014/limitations-of-gini-index (accessed 24 March 2017).

Keho, Y. 2011. Tax Structure and Economic Growth in Cote d'Ivoire: Are Some Taxes Better than Others? Asian Economic and Financial Review, 1(4), 226-235.

King, R., and Rebelo, S. 1990. Public Policy and Economic Growth: Developing Neoclassical Implications. Journal of Political Economy, 98(5), 126-150.

Lee, Y.M., and Roger, H. 2005. Tax structure and economic growth, Journal of Public Economics, 89(0), 1027-1043.

Margareta, D. and H. Åsa, 2012. Taxation of income and economic growth: An empirical analysis of 25 rich OECD countries. Journal of Economic Development, 21(1): 93-118.

Naiyeju, J.K.1996. Improving the Nigeria tax system from Canadian experience. Wordsmith Printing and Packaging Ltd. pp: 101-104.

Nantob, N. 2014. Taxes and Economic Growth in Developing Countries: A Dynamic Panel Approach. MPRA Paper No. 61346, posted 7 February 2015 02:40 UTC. [Accessed Online 03/01/2017] at https://mpra.ub.uni-muenchen.de/61346/.

Njogu L.K. 2015. The effect of value added tax on economic growth in Kenya. International Academic Journal of Economics and Finance,1(5),10-30.

Ogbonna, G., and Ebimobower, A. 2012. Impact of tax reforms on economic growth of Nigeria: A time series analysis. Current Research Journal of Social Science, 4 (1), 62-68.

Pesaran, M. H., Shin Yongcheol, and Smith, R. J. 2001. Bounds Testing Approaches to the Analysis of Level Relationships. Journal of Applied Econometrics (16) 289-326.

Saibu, O.M., 2015. Optimal tax rate and economic growth. Evidence from Nigeria and South Africa. Euro Economical Issue, 34(1): 41-50. 
Saima, S, Tariq, A, Muhammad, F.R, Sofia, A, and Amir, A. 2014. Taxation effects on economic activity in Pakistan. Journal of Finance and Economics, 6(2): 215-219.

Salami, G.O., K.H. Apelogun, O.M. Omidiya and O.F. Ojoye, 2015. Taxation and Nigerian economic growth process. Research Journal of Finance and Accounting. 6(10).

Sekou, M., 2015. The impact of tax collection in achieving revenue targets: The directorate general of taxes of Mali case study. Theoretical Economics Letters, 5: 403409. DOI http://dx.doi.org/10.4236/tel.2015.53046.

Skinner, J. 1987. Taxation and Output Growth: Evidence from African Countries. NBER Working Paper Series No. 2335. Cambridge, MA: National Bureau of Economic Research.

Solow, R.M. 1956. A Contribution to the Theory of Economic Growth. The Quarterly Journal of Economics, 70(1), 65-94. https://doi.org/10.2307/1884513.

Statistics South Africa. 2017. Quarterly Employment Statistics. 14 February 2017 Pretoria, Government printer.

Stoilova, D and Patonov, N. 2012. An Empirical Evidence for the Impact of Taxation on Economy Growth in the Eurpean Union. Tourism and Management Studies International Conference Algarve.

Taha, R., Loganathan., Nanthakumar., and Colombage, S.R.N. 2011. The Effect of economic Growth on Taxation Revenue: The Case of a Newly Industrialized Country. International Review of Business Research Papers, 7(1), 319-329.

Takumah, W. 2014. Tax Revenue and Economic Growth in Ghana: A Cointegration Approach. MPRA Paper No. 58532, posted 13. September 2014 03:44 UTC. [Accessed Online 03/01/2017] at Online at http://mpra.ub.uni-muenchen.de/58532/

Umoru,D and Anyiwe, MA. 2013. Tax structures and economic growth in Nigeria: Disaggregated empirical evidence. Journal of Finance and Accounting, 4(2).65-79.

Unegbu, AO and Irefin, D2011. Impact of VAT on Economic Development of Emerging nations. Journal of Economics and International Finance. 3(8), 492-503. 
Wisdom T 2014. Tax Revenue and Economic Growth in Ghana: A Cointegration Approach. MPRA. pp. 58532. Online at http://mpra.ub.uni-muenchen.de/58532/.

Yaya, K. 2013. The structure of taxes and economic growth in Cote d"ivoire: An econometric investigation. Journal of Research in Economics and International Finance, (JREIF.) 3(2):39-48. 